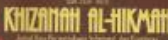

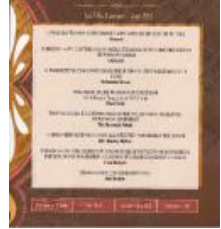

\section{IMPLEMENTASI TEORI HIRARKI KEBUTUHAN ABRAHAM MASLOW TERHADAP PENINGKATAN KINERJA PUSTAKAWAN}

Iskandar*

Pengutipan: Iskandar. (2016). Implementasi Teori Hirarki Kebutuhan Abraham Maslom terhadap peningkatan kinerja pustakawan. Jurnal Ilmu Perpustakaan, Informasi, dan Kearsipan Khizanah AlHikmah, 4(1), 24-34.

*Mahasiswa Program Pascasarjana Konsentrasi Ilmu Perpustakaan dan Informasi UIN Sunan

Kalijaga, Yogyakarta

(iskandarngali94@gmail.com)

\begin{abstract}
ABSTRAK
Salah satu faktor yang menentukan maju dan mundurnya suatu organisasi adalah keberadaan sumber daya manusianya. Manusia dapat menjadikan organisasi efektif, dan merancang seluruh operasional organisasi, sampai menghasilkan produk, jasa, mengendalikan mutu, memasarkan, mengalokasi sumber-sumber daya lain dan menetapkan strategi tujuan organisasi. Keberadaan sumber daya manusia yang memiliki kemampuan yang berkualitas baik secara pengetahuan, keterampilan, maupun sikap, akan membuat suatu organisasi mudah mencapai tujuan yang ditetapkan. Karena sumber daya manusia adalah kunci yang mengerakan roda organisasi sehingga bisa berjalan secara dinamis. Artikel ini akan mengkaji teori hirarki Abraham Maslow terhadap peningkatan kinerja pustakawan. Sebagai pembanding, teori kebutuhan Clelland yang lebih melihat manusia pada sudut pandang hasrat untuk mengaktulisasi dirinya dengan dorongan untuk berprestasi yang tinggi, kekuasaan yang selalu melekat, dan afiliasi yang menjadi perekat dalam rantai organisasi sangat memperlihatkan penguburan akan kepuasan pribadi untuk bergerak secara dinamis dan bersaing secara ketat

Kata Kunci: Kinerja pustakawan, Teori hirarki Abraham Maslow, Teori Motivasi Kebutuhan McClelland
\end{abstract}

\title{
ABSTRACT
}

One should concern in how to keep an organization keeps balanced is depending on its human resources. Humanbeings can make an organization effectively works, and might design all operational works, till to produce value things, to control its quality measurments, to promote, in which above all is to achiece the organization goals. Having such a quality person within an organization might lead to success. The current study investigates Maslow's hierarchy of needs theory and McClelland's human motivation theroy that being used in many organization around the globe, including library. The study is a library research in which it will discover the impact of the theories within library as an information institution that worked human resources to establish.

Key Words: Librarian performance, Maslow's hierarchy of needs theory, McClelland's human motivation theory 


\section{PENDAHULUAN}

Salah satu faktor yang menentukan maju dan mundurnya suatu organisasi adalah keberadaan sumber daya manusianya. Manusia dapat menjadikan organisasi efektif, dan merancang seluruh operasional organisasi, sampai menghasilkan produk, jasa, mengendalikan mutu, memasarkan, mengalokasi sumber-sumber daya lain dan menetapkan strategi tujuan organisasi. Keberadaan sumber daya manusia yang memiliki kemampuan yang berkualitas baik secara pengetahuan, keterampilan, maupun sikap, akan membuat suatu organisasi mudah mencapai tujuan yang ditetapkan. Karena sumber daya manusia adalah kunci yang mengerakan roda organisasi sehingga bisa berjalan secara dinamis.

Perpustakaan sebagai suatu organisasi juga menitik beratkan kemajuannya pada kebearadaan sumber daya manusia. Dalam konteks ini pustakawan dipandang menjadi pionir pergerakan perpustakaan, sekaligus faktor kunci yang akan menentukan keberhasilannya. Ruang gerakan perpustakaan sangat ditentukan oleh pergerkan pustakawan. Apabila pustakawan statis dalam menciptakan trobosan-trobosan baru, bisa dipastikan perpustakaan tidak akan melakukan inovasi-inovasi dalam menghadapi kemajuan teknologi, informasi dan budaya, yang sejatinya menjadi bagian dari kerja perpustakaan. Membangkitkan motivasi kerja pustakawan menjadi jawaban dalam menciptakan perpustakaan yang berkelas. Sensitif terhadap perubahan prilaku pengguna, dan selalu mengembangakan hal-hal yang baru dalam menujang terlaksananya transfer informasi yang menyeluruh pada semua level masyarakat.
Motivasi (motivation) dapat diartikan sebagai kekuatan yang muncul dari dalam ataupun dari luar diri seseorang dan membangkitkan semangat serta ketekunan untuk mencapai sesuatu yang diinginkan. Dalam teori isi (content theoris) menegaskan bahwa kebutuhanlah yang yang memotivasi seseorang. Sejatinya setiap manusia selalu mempunyai kebutuhan yang diupayakan untuk dipenuhi. Motivasi adalah faktor utama yang mendorong seseorang untuk melakukan segala macam aktivitasnya dalam suatu lingkungan kerja organisasi, oleh karena itu motivasi sering dianggap pula sebagai faktor pendorong prilaku seseorang. Sehingga dalam hal ini dapat disimpulkan bahwa seseorang setiap ingin melakukan aktivitasnya pasti memiliki faktor pendorong tertentu. Oleh karena itu faktor pendorong dari seseorang untuk melakukan suatu aktifitas tertentu pada umumnya adalah kebutuhan serta keinginan orang tersebut itu sendiri.

Berdasarkan hasil penelitiaan Julia Wiranto $\mathrm{dkk}$, tentang hubungan motivasi dan kinerja pustakawan ditemukan bahwa, motivasi memiliki hubungan yang erat dengan kinerja pustakawan dalam mendukung tercapainya tujuan organisasi secara hirarkis. Motivasi menjadi topik yang cukup menarik untuk didiskusikan dalam kaitannya dengan peningkatan kinerja pustakawan. Untuk mengurai hubungan motivasi dan kinerja pustakawan teori hirarki kebutuhan Abraham Maslow saya kira sangat representatif untuk digunakan sebagai kerangka teoritis, agar membawa kita pada satu pemahaman yang lebih luas, dalam menyelesaikan problem pustakawan yang selama ini dianggap tidak mendapatkan perhatian yang memadai. Baik secara moril, materil 
maupun perlindungan secara hukum terhadap profesi pustakawan, yang berdampak secara signifikan pada kinerja pustakawan.

\section{Sekilas Tentang Biografi Abraham Maslow}

Abraham H. Maslow dilahirkan pada tahun 1908 dalam keluarga imigran RusiaYahudi di Brooklyn, New York. Ia seorang yang pemalu, neurotik, dan depresif namun memiliki rasa ingin tahu yang besar dan kecerdasan otak yang luar biasa. Dengan IQ 195, ia unggul di sekolah. Ketika beranjak remaja, Maslow mulai mengagumi karya para filsuf seperti Alfred North Whitehead, Henri Bergson, Thomas Jefferson, Abraham Lincoln, Plato, dan Baruch Spinoza. Di samping berkutat dalam kegiatan kognitif, ia juga mempunyai banyak pengalaman praktis. Ia bekerja sebagai pengantar koran dan menghabiskan liburan dengan bekerja pada perusahaan keluarga.

Maslow hidup dalam zaman di mana bermunculan banyak aliran psikologi yang baru tumbuh sebagai disiplin ilmu yang relatif muda. Di Amerika, William James mengembangkan Fungsionalisme. Psikologi Gestalt berkembang di Jerman, Sigmund Freud berjaya di Wina, dan John B. Watson mempopulerkan Behaviorisme di Amerika. Ketika pada tahun 1954 Maslow menerbitkan bukunya yang berjudul Motivation and Personality, dua teori yang sangat populer dan berpengaruh di universitas-universitas Amerika adalah Psikoanalisa Sigmund Freud dan Behaviorisme John B. Watson.

Dalam ranah psikologi, psikoanalisa Freud dianggap mazhab (force) pertama. Sedangkan behaviorisme disebut mazhab kedua. Agaknya Maslow (kendati pernah mengagumi kedua aliran tersebut) mempunyai prinsip yang berbeda. Sampel penelitian Freud adalah pasien-pasien neurotis dan psikotis di kliniknya. Pertanyaan kita adalah: bagaimana kesimpulan dari sampel orang-orang yang terganggu jiwanya dapat diterapkan pada orang-orang pada umumnya (yang sehat mental). Maslow mempunyai prinsip bahwa sebelum mengerti penyakit mental, orang harus terlebih dahulu memahami kesehatan mental.

Di kutub lain, kaum behavioris menghimpun data dari penelitian atas binatang seperti burung merpati dan tikus putih. Maslow melihat bahwa kesimpulan mereka bisa jadi berlaku bagi ikan, katak, atau tikus, tetapi tidak untuk bangsa manusia.

Berlawanan secara radikal dengan kedua aliran tersebut, Maslow mencari sampel pada manusia-manusia yang dalam masyarakat dilihat sebagai "tokoh". Ia melibatkan penelitiannya terhadap tujuh tokoh modern dan sembilan tokoh sejarah: Abraham Lincoln dan Thomas Jefferson (presiden AS), Eleanor Roosevelt (First Lady yang dermawan), Jane Addams (pelopor pekerja sosial), William James (psikolog), Albert Schweitzer (dokter dan humanis), Aldous Huxley (penulis), dan Baruch Spinoza (filsuf).

Penyelidikan tentang tokoh-tokoh ini (dan yang lainnya) - kebiasaan, sifat, kepribadian, dan kemampuan mereka telah mengantar Maslow sampai pada teori tentang kesehatan mental dan teori tentang motivasi pada manusia. Secara dialektis, tesis Freud dan antitesis Watson, melahirkan sintesis Abraham Maslow. Oleh karena itu, teorinya kerap disebut mazhab ketiga. 


\section{KERANGKA TEORI}

Abraham Maslow beranggapan bahwa semua motivasi terjadi sebagai reaksi atas persepsi seseorang individu atas lima macam tipe dasar kebutuhan. Menurut Maslow, terdapat 5 macam kebutuhan dasar, yang senantiasa dialami seseorang individu. Teori Hierarki Kebutuhannya sendiri Maslow menyebutknya sebagai sintesis atau perpaduan teori yang holistik dinamis. Disebut demikian karena Maslow mendasarkan teorinya dengan mengikuti tradisi fungsional James dan Dewey, yang dipadu dengan unsur-unsur kepercayaan Wertheimer, Goldstein, dan psikologi Gestalt, dan dengan dinamisme Freud, Fromm, Horney, Reich, Jung, dan Adler.

\section{a. Kebutuhan Fisiologis (Physiological Needs)}

Kebutuhan fisiologis terdiri dari kebutuhan dasar, dan yang bersifat primer. Kadang-kadang mereka dinamakan kebutuhan-kebutuhan biologikal dalam lingkungan kerja modern dan termasuk di dalamnya keinginan untuk mendapatkan pembayaran (upah/gaji), libur, rencanaracana pensiun, periode-periode istirahat, lingkungan kerja yang menyenangkan, penerangan yang baik dan pada tempattempat kerja tertentu fasilitas AC. Kebutuhan fisiologis adalah kebutuhan yang paling kuat dan mendesak yang harus dipenuhi paling utama oleh manusia dalam menjalankan kehidupan kesehariannya. Ini berarti bahwa pada diri manusia yang sangat merasa kekurangan segala-galanya dalam kehidupannya, besar sekali kemungkinan bahwa motivasi yang paling besar ialah kebutuhan fisiologis dan bukan yang lainlainnya. Dengan kata lain, seorang individu yang melarat kehidupannya, mungkin sekali akan selalu termotivasi oleh kebutuhan-kebutuhan ini.

\section{b. Kebutuhan Akan Rasa Aman (Safety Needs)}

Setelah kebutuhan fisiologis terpenuhi, maka akan muncul kebutuhan akan keamanan, atau kebutuhan akan kepastian. Orang yang merasa tidak aman memiliki kebutuhan akan keteraturan dan stabilitas serta akan berusaha keras menghindari hal-hal yang bersifat asing dan tidak diharapkan.

Kebutuhan akan keamanan merefleksi beinginan untuk mengamankan imbalanimbalan yang telah dicapai dan untuk melindungi diri sendiri terhadap bahaya, cedera, ancaman, kecelakaan, kerugian atau kehilangan. Pada organisasiorganisasi kebutuhan-kebutuhan demikian terlihat pada keinginan pekerjaan akan kepastian pekerjaan, sistem-sistem senioritas, serikat pekerja, kondisi kerja aman, imbalan-imbalan tambahan, asuransi, dan kemungkinan pensiun, tabungan, dan uang tunggu apabila terjadi hal-hal tertentu.

\section{c. Kebutuhan Untuk Diterima (Social Needs)}

Seteleh kebutuhan fisiologikal dan keamanan selasai dipenuhi, maka perhatian sang individu beralih pada keinginan untuk mendapatkan kawan, cinta dan perasaan diterima. Sebagai mahluk sosial, manusia senang apabila mereka disenangi, dan berusaha memenuhi kebutuhan sosial pada waktu mereka bekerja, dengan jalan membantu kelompok-kelompok formal maupun informal, dan mereka bekerja sama dengan rekan-rekan sekerja mereka, dan mereka turut terlibat dalam kegiatan yang 
dilaksanakan oleh perusahaan dimana mereka bekerja.

\section{d. Kebutuhan Untuk Dihargai (Self Esteem Needs)}

Pada tingkatan keempat hieraki Maslow, terlihat kebutuhan individu akan penghargaan, atau juga dinamakan orang kebutuhan "ego". Kebutuhan ini berhubungan dengan hasrat yang untuk memiliki citra positif dan menerima perhatian, pengakuan, dan apresiasi dari orang lain. Dalam organisasi kebutuhan untuk dihargai menunjukan motivasi untuk diakui, tanggung jawab yang besar, status yang tinggi, dan pengakuan atas kontribusi pada organisasi.

\section{e. Kebutuhan Aktualisasi-Diri (Self Actualization)}

Kebutuhan ini adalah kebutuhan untuk mengalami pemenuhan diri, yang merupakan kategori kebutuhan tertinggi. Kebutuhan ini diantaranya adalah kebutuhan untuk mengembangkan potensi yang ada pada diri sendiri secara menyeluruh, meningkatkan kemampuan diri, dan menjadi orang yang lebih baik. Kebutuhan aktualisasi diri oleh organisasi dapat dipenuhi dengan memberikan kesempatan orang-orang untuk tumbuh, mengembangkan kreativitas, dan mendapatkan pelatihan untuk mendapatkan tugas yang menantang serta melakukan pencapaian.

Richard L.Daft membuatnya lebih spesifik dalam satu gambaran sebagai berikut.

\begin{tabular}{|c|c|c|}
\hline $\begin{array}{l}\text { Pemenuhan di luar } \\
\text { Pekerjaan }\end{array}$ & $\begin{array}{l}\text { Hirarki Kebutuhan } \\
\text { Manusia }\end{array}$ & $\begin{array}{c}\text { Pemenuhan dalam } \\
\text { Pekerjaan }\end{array}$ \\
\hline $\begin{array}{l}\text { Pendidikan, Religi, } \\
\text { Hobi, Pertumbuhan } \\
\text { Pribadi }\end{array}$ & Kebutuhan Aktualisasi-diri & $\begin{array}{l}\text { Kesempatan untuk pelatihan, } \\
\text { kemajuan, pertumbuhan dan } \\
\text { kreatifitas. }\end{array}$ \\
\hline $\begin{array}{l}\text { Persetujuan } \\
\text { keluarga, teman, } \\
\text { komunitas }\end{array}$ & Kebutuhan untuk dihargai & $\begin{array}{l}\text { Pengakuan, status tinggi, } \\
\text { meningkatkan tanggung jawab }\end{array}$ \\
\hline $\begin{array}{l}\text { Keluarga, teman, } \\
\text { grup komunitas }\end{array}$ & Kebutuhan untuk diterima & $\begin{array}{c}\text { Kelompok kerja, rekan kerja, } \\
\text { supervisor }\end{array}$ \\
\hline $\begin{array}{l}\text { Bebas dari perang, } \\
\text { polusi, kekerasan }\end{array}$ & Kebutuhan akan rasa aman & $\begin{array}{c}\text { Kerja yang aman, tunjangan kerja, } \\
\text { jaminan }\end{array}$ \\
\hline $\begin{array}{l}\text { Makanan, Air, } \\
\text { Oksigen }\end{array}$ & Kebutuhan fisiologis & Panas, udara, gaji pokok \\
\hline
\end{tabular}




\section{TEORI PEMBANDING}

Dalam teori Abraham Maslow kebutuhan yang memotivasi manusia dalam bekerja dibagi menjadi lima bagian kebutuhan, sebagai pembanding pemikiran Maslow penulis menggunakan teori David Mc. Clelland yang membagi kebutuhan manusia menjadi tiga pokok utama:

\section{a. Kebutuhan Akan Prestasi ( The Need For Achievement)}

Dinyatakan oleh McClelland bahwa kebutuhan akan prestasi, secara positif berkaitan dengan hasil pekerja manejarial, dan sukses yang dicapainya, dan kita dapat mengembangkan suatu kebutuhan akan prestasi pada manajer-manajer, yang beraspirasi. Para individu yang menunjukan oriantasi prestasi tinggi, menunjukan ciri-ciri:

Bersedia menerima resiko tingkat relatif tinggi.

Suatu keinginan untuk mendapatkan feedbeck konkret tentang hasil prestasi mereka.

$>$ Suatu keinginan untuk mendapatkan tanggung jawab pemecahan masalah

dan suatu kecenderungan untuk menetapkan tujuan-tujuan yang bersifat moderat.

Para manajer yang ingin memahami, dan menciptakan suatu lingkungan kreatif untuk para bahwahan meraka dengan kebutuhan-kebutuhan akan prestasi tinggi, harus mengetahui bahwa mereka mencapai satisfaksi terutama dari proses menginisiasi, melaksanakan dan menyelesaikan sesuatu pekerja - dan mereka kurang begitu berpengaruh oleh imbalan-imbalan yang muncul apabila sesuatu pekerjaan dilaksanakan dengan baik.

\section{b. Kebutuhan Akan Kekuasaan (The Need For Power)}

Kebutuhan ini merupakan suatu ekspresi dari keinginan seseorang individu untuk mengendalikan dan mempengaruhi pihak lain. McClelland melihatnya sebagai suatu sifat yang positif, dan dengan demikian kebutuhan akan kekuasaan sangat dekat berhubungan dengan keinginan untuk mencapai suatu posisi kepemimpinan.

Mc. Clelland beranggapan bahwa terdapat berbagai macam tahapan dalam pengembangan ide seseorang individu, tentang tujuan kekuasaan dan bahwa para manajer dapat dilatih untuk menolak pandangan bahwa orang hendaknya jangan mencoba mempengaruhi orang lain.

c. Kebutuhan Akan Afiliasi (The Need For Affliation)

Kebutuhan akan afiliasi dari McClelland ditekankan pada refleksi keinginan untuk mempunyai hubunganhubungan erat, koorporatif dan penuh sikap persahabatan dengan pihak lain. Para individu yang memiliki kebutuhan afiliasi tinggi, pada umumnya berhasil dalam pekerjaan di mana hubunganhubungan antar-perorangan terutama bersifat amat kritikal bagi hasil pekerjaan.

\section{ANALISIS TEORI}

Dalam menentukan kebutuhan manusia Abraham Maslow sangat menekan pada pemenuhan kebutuhan yang sangat bersifat internal di dalam manusia. Terlihat sekali pada penempatan faktor fisiologis pada posisi yang sangat 
mendasar yang harus dipenuhi. Sedangkan kebutuhan yang bersifat external yang berhubungan dengan dunia luar dari manusianya itu ditempatkan pada posisi yang terakhir. Maslow lebih menekankan kebutuhan yang membuat individu lebih cenderung statis. Pada kebutuhan akan rasa aman, pengakuan orang lain, dan penghargaan adalah keseruhan kebutuhan yang menunggu umpan balik dari orang lain untuk memenuhinya. Baru pada kebutuhan akan aktualisasi diri individu dibiarkan untuk bergerak secara dinamis untuk berhubungan dengan dunia luar.

Sedangkan McClelland dalam menentukan kebutuhan manusia lebih cenderung memberi titik tekan pada pemberian ruang gerak individu yang sangat dinamis. Di mana presatasi adalah usaha yang bisa diwujudkan dengan kerja keras dan persaingan yang ketat. Kebutuhan akan kekuasaan adalah wujud pembuktian diri atas presatasi yang sudah didapat dan membutuhkan dukungan orang lain yang sangat besar untuk meraihnya. Begitu juga dengan afiliasi yang bisa didapat dengan dukungan prestasi dan kekuasaan sebagai alat untuk meyakinkan individu lain masuk dalam rantai yang dibangun. Untuk mewujudkan kebutuhan dalam teori McClelland sangat menekankan pada agrefitas personal yang tinggi yang harus sudah ada dalam setiap individu. Dalam konteks ini benturan yang ketat antara individu satu dengan yang lain menjadi semakin besar, dinamika dalam organisasi juga akan lahir dengan sendirinya tanpa harus didesain secara khusus oleh pimpinan selama kebutuhan itu bisa ditopang. Pimpinan hanya akan fokus pada pengawalan dan pengetatan aturan main (rule of game) serta evaluasi hasil akhir.
Pada prinsip kerja organisasi teori Maslow dan McClellland sama-sama memberikan perhatian yang cukup besar terhadap pengembangan diri sumber daya manusia sebagai jembatan untuk bisa merenovasi diri secara cepat terutama dalam kaitannnya dengan perkembangan budaya, teknologi, dan informasi. Sehinga poin aktualisasi diri Maslow dan kesatuan kerja prestasi, kekuasaan dan afliasasi yang dibangun oleh Mc. Clelland bermuara pada pengembangan organisasi secara modern serta desain organisasi yang bisa bergerak maju.

\section{IMPLEMENTASI TEORI MASLOW DAN MCCLELLAND PADA PERPUSTAKAAN}

Untuk mencipatakan lingkungan kerja yang memotivasi di dalam organisasi, seorang pemimpin harus memahami konsep motivasi secara menyeluruh. Teori motivasi Maslow dan Clelland dapat membantu seorang pimpinan untuk menetukan strategi yang tepat dalam memotivasi bawahan. Sebab perbedaan motivasi berdampak pada berbedanya tujuan individual, yang nantinya akan menganggu terwujudnya cita-cita kolektif organisasi itu sendiri.

Dalam konteks perpustakaan, kehadiran teori Maslow dan Clelland tentang motivasi dapat menjadi satu rujukan ilmiah dalam membangun motivasi sumber daya manusia yang ada di perpustakaan. Motivasi dalam konteks perpustakaan akan mendorong SDM yang ada bekerja secara maksimal, hal ini penting karena perpustakaan adalah organisasi jasa informasi yang tidak menuntut profit dan menekan kepada kepuasan pengguna yang sangat tinggi. Sehingga untuk membangun motivasi dalam konteks ini membutuhkan 
kerangka teori yang membahas kebutuhan manusia secara menyeluruh.

Adapun implikasi positif kedua teori ini ke dalam perpustakaan adalah sebagai berikut.

a. Memenuhi Kebutuhan Fisiologis Adalah Langkah Pertama untuk Membangun Motivasi Pustakawan dalam Bekerja Kebutuhan fisiologis berkaitan dengan kesejahteraan pustakawan. Peningkatan kesejahteraan harus menjadi perioritas dalam setiap pengambilan kebijakan di setiap lembaga perpustakaan. Kesejateraan dapat menjadi penentu motivasi pustakawan dalam menjalankan tugasnya sebagai penanggungjawab pelayanan informasi kepada pengguna. Pemberian kompensasi adalah salah satu bentuk pemenuhan kebutuhan fisiologis dari pustakawan. Pemberian kompensasi merupakan salah satu fungsi yang penting dalam manajemen sumber daya manusia, terutama kaitannya dengan peningkatan motivasi kerja dari para karyawan.

Menurut Cascio (1993) kompensasi itu terbagi menjadi dua, terdapat kompensasi langsung dan kompensasi tidak langsung. Kompensasi langsung terdiri dari gaji, uang transport, tunjangan hari raya, uang lembur, dan tunjangan langsung lainnya. Sedangkan kompensasi tidak langsung terdiri dari promosi jabatan, asuransi, tunjangan jabatan, dan mutasi. Perhatian terhadap kesejateraaan pustakawan melalui pemberian kompensasi akan berdampak pada kinerja serta kenyamanan pustakawan dalam menjalankan tugasnya, sebagai tokoh kunci dalam menentukan maju mundurnya roda perpustakaan. b. Kepala perpustakaan dapat mengakomodasi kebutuhan akan rasa aman dalam organisasi dengan jalan membentuk dan melaksanakan standar-standar perilaku yang jelas. Dalam bekerja pustakawan harus dipastikan merasa aman, nyaman, serta mendapatkan kepastian dari setiap kerja yang dilakukan. Untuk memenuhi itu pustakawan harus mendapatkan kepastian terhadap proses kenaikan pangkat, pengumpulan angka kredit, serta perlindungan keamanan dalam bekerja.

Hal ini sejalan dengan pendapat Robbins dan Luthans (2002) bahwa karyawan biasanya sangat memperhatikan lingkungan tempat kerja mereka untuk kenyamanan pribadi dan untuk mendukung pekerjaan mereka. Mereka cenderung lebih menyukai fisik yang aman dan nyaman. Lingkungan kerja yang aman dan nyaman juga akan berdampak pada pola hubungan antara pustakawan yang satu dengan lainnya di dalam maupun di luar lingkungan kerja. Dimana menurut Robbins, bagi kebanyakan karyawan, tempat kerja juga merupakan tempat untuk sosialisasi, sehingga sangat penting bagi mereka untuk memiliki rekan kerja yang mendukung dan dapat bekerjasama dengan baik.

Pemenuhan kebutuhan akan keamanan, kenyamanan dan kepastian membuat pustakawan bisa bekerja secara maksimal, sehingga proses pemenuhan kebutuhan informasi pengguna bisa berjalan maksimal. Karena hampir setiap individu dalam tingkat kebutuhannya menginginkan ketenteraman, supervisi, dan peluang kerja yang bersinambung. 
c. Mendapatkan penghargaan bagi setiap manusia adalah capaian yang membanggakan. Banyak orang yang bekerja bertahun-tahun hanya untuk meraih satu penghargaan untuk dibuktikan kepada khalayak bahwa dia bisa. Tidak sedikit juga orang yang mundur dari pekerjaan atau bekerja tanpa motivasi, hanya karena tidak mendapatkan perhatian dari atasan atau reward selama dia menjadi karyawan. Faktor penghargaan harus menjadi pilar untuk membangun motivasi kerja sehingga tujuan organisasi bisa dilaksanakan secara kolektif dari atasan hingga kepada struktur yang paling bawah.

Pada lembaga perpustakaan pemberian penghargaan akan membantu menstimulus pustakawan untuk bekerja lebih produktif. Hal ini sejalan dengan pendapat Mikander (2010) yang mengatakan bahwa penghargaan dari perusahaan memiliki pengaruh yang sangat besar terhadap kinerja karyawan. Karyawan yang meningkatkan kinerjanya akan berdampak pada prestasi kerja. Semakin banyak karyawan yang memiliki prestasi kerja tentu perkembangan perusahaan semakin pesat dan tujuan perusahaan dapat dicapai.

Penghargaan bisa berwujud materil maupun non materil. Penghargaan materil bisa berupa pemberiaan tunjangan jabatan fungsional yang memadai, fasilitas kendaraan operasional, dan pemberiaan intensif khusus dari pemerintah maupun lembaga induk dimana perpustakaan itu ada.
Penghargaan non materiil bisa diberikan dalam bentuk beasiswa tugas belajar, mengikutsertakan dalam pelatihan maupun workshop untuk meningkatkan kompetensi sumber daya pustakawan. Serta pemberiaan penghargaan non materil juga bisa berupa pemberian kesempatan untuk pustakawan meraih prestasi dan pangkat yang memenuhi kenentuan untuk dipromosikan mendapatkan jabatan structural eselon IV, III, II di dalam dalam bidang perpustakaan.

Dampak pemberian penghargaan akan membuat pustakawan berusaha dengan keras membuktikan eksistensi dirinya dengan melahirkan prestasiprestasi yang membanggakan.

d. Memberi ruang kebebasan kepada pustakawan untuk mengekspresikan potensi yang mereka miliki bisa menjadi salah satu langkah untuk memotivasi mereka dalam bekerja dan dapat mengurangi tekanan psikologis. Dalam konteks ini karyawan akan lebih berpikir secara luas dan tidak ingin ditekan dengan aturan-aturan yang mengikat.

Pendapat ini sejalan dengan apa yang disampaiakn oleh Robbins (1996) yang menyatakan bahwa karyawan cenderung menyukai pekerjaan yang memberikan kesempatan pada mereka untuk membuktikan keterampilan dan kemampuan mereka, dan menyediakan tugas-tugas yang bervariasi, kebebasan dan umpan balik tentang hasil kerja yang mereka lakukan. Pekerjaan yang 
memiliki sedikit tantangan akan cepat membosankan mereka, sebaliknya, yang terlalu banyak tantangan akan menimbulkan frustasi dan kegagalan. Kondisi pekerjaan yang memiliki tantangan yang moderat akan menumbuhkan kepuasan dalam diri karyawan.

$\begin{array}{lcr}\text { Ketika ruang } & \text { kebebasan mampu } \\ \text { diwujudkan } & \text { di } & \text { lembaga } \\ \text { perpustakaan } & \text { maka } & \text { akan }\end{array}$ berdampak pada semakin mudah proses aktualisasi diri pustakawan. Aktualisasi diri adalah proses di mana pustakawan harus difasilitasi untuk mengembangkan profesinya sebagai agen informasi, ilmuwan, dan pendidik professional, yang dapat memberikan berbagai macam umpan balik positif kepada pustakawan berupa citra positif perpustakaan kepada masyarakat. Aktualisasi diri pustakawan dapat berupa pelibatan pustakawan secara langsung dalam proses pembinaan minat baca masyarakat. Melalui pembuatan taman baca yang dikelola secara terintegrasi oleh pustakawan, dengan melibatkan semua elemen masyarakat, pemerintah, dan sponsor-sponsor.

Proses aktualisasi yang terjadi pada diri pustakawan akan mengarahkan pustakawan pada upaya untuk membangun afiliasi lintas profesi maupun keilmuan. Afiliasi dalam hal ini satu cara yang dilakukan untuk menguatkan konsolidasi organisasi baik dalam hubungan individu, maupun dalam kaitannya dengan tujuan organisasi. Terwujudnya suatu hubungan yang bisa berdampak pada terciptanya ruang gerakan perpustakaan yang lebih luas. Karena perpustakaan masa depan sangat membutuhkan koneksi dengan penyedia informasi yang lain untuk membantu penyebaran dan keterbatasan informasi yang dimiliki.

e. Kebutuhan akan kekuasan adalah bagian dari pada usaha pustakawan untuk mempengaruhi orang lain dalam rangka mewujudkan tujuan pribadi yang masih berada pada tujuan organisasi. Kebutuhan kekuatan adalah keinginan untuk memiliki pengaruh, menjadi yang berpengaruh, dan mengendalikan individu yang lain.

Individu kebutuhan yang tinggi suka bertanggung jawab, berjuang untuk mempengaruhi individu lain, senang ditempatkan dalam situasi yang kompetitif dan berorientasi status, serta cenderung lebih khawatir dengan wibawa dan mendapatkan pengaruh atas individu lain daripada kinerja yang efektif. Kekuasan yang ingin dicapai akan dilegitimasi dengan prestasi yang disudah diraih. Ketika seorang pustakawan menduduki posisi terntu pustakawan yang lain akan memberi dukungan walaupun suasana organisasi akan sangat kompetitif.

\section{KESIMPULAN}

Pemikiran Abraham Maslow memberi kita satu petunjuk yang komprehensif dalam mengkaji kebutuhan yang bisa memotivasi manusia lebih khusus dalam suatu organisasi. Teori hirarki kebutuhan menitik beratkan pada pemenuhan kebutuhan dasar manusia secara fisik, lalu berlanjut pada kebutuhan yang bersifat 
external yang berhubungan dengan dunia luar secara vertikal maupun horizontal dalam bingkai hirarki organisasi. Sebagai pembanding, teori kebutuhan Clelland yang lebih melihat manusia pada sudut pandang hasrat untuk mengaktulisasi dirinya dengan dorongan untuk berprestasi yang tinggi, kekuasaan yang selalu melekat, dan afiliasi yang menjadi perekat dalam rantai organisasi sangat memperlihatkan penguburan akan kepuasan pribadi untuk bergerak secara dinamis dan bersaing secara ketat.

Pada prinsipnya pemikiran Maslow amatlah sangat terstruktur dalam mengurai kebutuhan manusia. Hadirnya pemikiran McClelland lebih pada posisi menjabarkan pemikiran Maslow dalam kerangka kebutuhan eksternal yang dibutuhkan oleh manusia secara lebih luas.

Kedua teori ini sesungguhnya samasama menyentuh pada kerangka pengembangan organisasi keluar dengan titik tekannya pada pemberian kepercayaan yang lebih kepada sumber daya manusia yang ada. Akhirnya pada organisasi akan berkembang dan berinovasi secara dinamis karena organisasi akan terus diwarnai oleh dinamika yang menjadi ciri organisasi modern.

\section{DAFTAR PUSTAKA}

Butler-Bowdon, Tom. Self-Help Classics. Diterjemahkan oleh Rachma Christiani Subekti. Jakarta: Bhuana Ilmu Populer. 2005.

D. Mc. CLelland, The Achieving Society, J. van Nostrand, Princeton, N.J.,1961.

Eko Nugroho dkk. "Pengaruh Coaching

Terhadap Motivasi Kerja dan

Kinerja Individual" (Studi Kasus pada Karyawan Bagian Support Services Departemen Production Services PT. International Nikel Indonesia, Tbk)

Luthans, F. Organizational Behaviour, International Edition, Mc GrawwHill Book Co, Singapore, 1992.

Goble, Frank G. 1987. Mazhab Ketiga: Psikologi Humanistik Abraham Maslow, (Judul asli:The Third Force, The Psychology of Abraham Maslow), Diterjemahkan oleh Drs. A. Supratiknya, Yogyakarta: Kanisius, 1989.

Maslow, Abraham H. 1984. Motivasi dan Kepribadian: Teori Motivasi dengan Ancangan Hirarki Kebutuhan Manusia (judul asli: Motivation and Personality). Diterjemahkan oleh Nurul Iman. Jakarta: PT. Pustaka Binaman Pressindo.

Mikander, C. The Impact of a Reward System on Employee Motivation in MononetEspoo. Thesis. Arcada., 2010.

Richard L.Daft, Era baru Menejemen : New era Of Management, Jakarta: Salemba Empat. 2012.

Robbins, S.P and Tomoty A. Judge. Organizational Behaviour, Seventh Edition, Prentice Inc. New Jersey, 1996.

Winardi, Asasi-Asas Manajemen Bandung : Mandar Maju, 2010, Dikutip dari Abraham Maslow, Motivation and Personality, harper \& Row, New York 1954.

Winardi, J. Motivasi dan Pemotivasian dalam Manajemen. Jakarta: PT. Raja Grafindo Persada. 2002. 